\title{
$>$ Oralidade, Escrita e Estilo em Platão e Montaigne
}

> Orality, Writing and Style in Plato and Montaigne

\section{por Bruno Alonso}

Doutorando em Filosofia pelo Programa de Pós-Graduação em Filosofia (PPGF) da Universidade Federal do Rio de Janeiro (UFRJ). E-mail: brunoalonso@id.uff.br. ORCID: 0000-0003-0534-2950.

\begin{abstract}
Resumo
A crítica de Platão à escrita se situa em meio ao conflito entre o mundo oral e a cultura escrita. Platão escreveu diálogos que são claramente o retrato de discussões que ocorreram na vida real, tenham ou não acontecido verdadeiramente. Os Ensaios de Montaigne, por outro lado, são monólogos que estabelecem uma interlocução com o leitor. Ambos tentaram de alguma forma superar a artificialidade da escrita trazendo ao texto a mesma versatilidade e vivacidade do discurso oral. Montaigne escreveu em uma época na qual muitas obras em forma de diálogo circulavam, sendo então um gênero literário conhecido e influente na sua época. Os Ensaios emergem no contexto histórico do Renascimento com uma originalidade sem precedentes. Seria admissível julgar o estilo ensaístico de Montaigne como um novo gênero literário produzido com a pretensão de superar a forma de diálogo?
\end{abstract}

Palavras-chave: Platão. Montaigne. Diálogo. Ensaio. Estilo.

\begin{abstract}
Plato's critique of writing lies amid the conflict between the oral world and written culture. Plato wrote dialogues that are clearly the reflection of discussions that occurred in real life, whether or not they actually took place. Montaigne Essays, on the other hand, are monologues that establish an interlocution with the reader. Both have somehow tried to overcome the artificiality of writing by bringing to the text the same versatility and vivacity of oral speech. Montaigne wrote at a time when many works in the form of dialogue circulated, being then a literary genre known and influential in his time. The Essays emerge in the historical context of the Renaissance with unprecedented originality. Would be permissible to judge Montaigne's essayistic style as a new literary genre produced with intention of overcoming the form of dialogue? Keywords: Plato. Montaigne. Dialogue. Essay. Style.
\end{abstract}




\section{Acerca da crítica de Platão à escrita no Fedro e na Carta VII}

No diálogo Fedro, Sócrates narra um mito egípcio sobre o deus Thoth, a divindade responsável pela invenção da escrita. Thoth revela suas invenções ao monarca Tamuz, que avalia os benefícios ou malefícios advindos das artes apresentadas. Sócrates atenta para o julgamento de uma única arte, a escrita:

[...] quando chegou a vez da invenção da escrita, exclamou Thoth: Eis, oh Rei, uma arte que tornará os egípcios mais sábios e os ajudará a fortalecer a memória, pois com a escrita descobri o remédio para a memória. - Oh, Thoth, mestre incomparável, uma coisa é inventar uma arte, outra julgar os benefícios ou prejuízos que dela advirão para os outros! Tu, neste momento e como inventor da escrita, esperas dela, e com entusiasmo, todo o contrário do que ela pode vir a fazer! Ela tornará os homens mais esquecidos, pois que, sabendo escrever, deixarão de exercitar a memória, confiando apenas nas escrituras, e só se lembrarão de um assunto por força de motivos exteriores, por meio de sinais, e não dos assuntos em si mesmos. $^{1}$

Empolgado com seu invento, Thoth acredita ter criado uma excelente ferramenta que tornaria os homens mais sábios, pois a escrita serviria como instrumento capaz de exercitar e fortalecer a memória. Tamuz não compartilha do seu entusiasmo e alerta para o perigo trazido pela invenção da escrita, um instrumento pernicioso para a memória. A capacidade de representar as palavras fora do âmbito oral, ao contrário de fortalecer a memória, faria com que essa se tornasse mais preguiçosa e inábil para lembrar por si mesma. $\mathrm{O}$ advento da escrita, diferente da expectativa do deus Thoth, debilita a vocação natural da memória, que se torna cada vez mais dependente de um recurso exterior e estranho a ela mesma. Essa dependência faria com que os homens perdessem de vista aquilo que realmente fortalece a memória, a palavra oral atrelada ao exercício interior e meditativo, o único meio efetivo de manter a memória sã.

Ao apresentar esse mito, Platão pretende mostrar o aspecto conflituoso entre a oralidade e a cultura escrita. Essa temática aparece, especialmente, em dois textos determinados: no Fedro (274e - 275b) e na Carta VII. É estranho pensar que Platão foi tão severo ao fazer Sócrates dizer que a escrita traz tantos

\footnotetext{
${ }^{1}$ Platão, Fedro, 1989, 274e-275a.
} 
malefícios à mente e, ao mesmo tempo, fazer isso recorrendo à própria escrita como instrumento de transmissão das suas ideias. Platão parece se referir a uma espécie de infância da humanidade, quando a comunicação ocorria tão somente mediante a fala. A escrita é um produto elaborado pelo homem, uma característica que representa e se refere à palavra falada. Mas há um outro aspecto que aumenta mais ainda esse estranhamento frente à crítica de Sócrates à escrita. Em A República, Platão expulsa os poetas da sua cidade ideal. Poetas estes que representam a tradição homérica, que se destaca pelo aprendizado dos mitos declamados em público, principalmente durante as festividades e as cerimônias dedicadas aos deuses. Era um contexto em que prevalecia a habilidade dos rapsodos, que cantavam versos da Ilíada e da Odisséia de Homero, sem recorrerem à escrita. A cultura escrita era ainda nesse período algo incipiente, além de não existirem técnicas sofisticadas de reprodução, o que impossibilitava uma difusão em massa dos textos.

O impacto da crescente popularização da cultura escrita, no ambiente cultural da Grécia antiga, pode ser interpretado como um fenômeno parecido ao que acontece atualmente no mundo contemporâneo, após a invenção do computador e o desenvolvimento de outras tecnologias. Ong chama atenção para o fato de que Platão foi capaz de perceber precocemente os efeitos da escrita sobre a inteligência, consciente de como essa influência se propagaria sendo cada vez mais internalizada pelo ser humano.

A escrita, a impressão e o computador são todos meios de tecnologizar a palavra. Tecnologizada a palavra, não há um meio convincente de criticar o que a tecnologia fez com ela sem o auxílio da mais alta tecnologia disponível. Além disso, a nova tecnologia não é meramente usada para veicular a crítica: na verdade, ela criou a crítica. O pensamento filosoficamente analítico de Platão, [...] incluindo sua crítica à escrita, só se tornou possível em virtude dos efeitos que a escrita estava começando a ter sobre os processos mentais. [...] $\mathrm{Na}$ verdade, como mostrou brilhantemente Havelock (1963), toda a epistemologia de Platão era inconscientemente uma rejeição programada do mundo da velha vida cotidiana oral, móvel, calorosa, individualmente interativa (representada pelos poetas, a quem ele expulsara de sua República). O termo idea, "forma", está fundado no visual e procede da mesma raiz que o latim video, "ver", assim como os derivados em língua portuguesa "visão", "visível" ou "vídeo". A forma platônica foi concebida por analogia à forma visível. As ideias platônicas são mudas, imóveis, desprovidas de todo calor, não são 
interativas, mas isoladas, não são absolutamente partes do mundo cotidiano humano, estão inteiramente acima e além dela. Platão, é claro, não se tinha dado totalmente conta das forças inconscientes que atuavam em sua psique para produzir essa reação, ou reação exagerada, do indivíduo letrado à oralidade subsistente, tardia. ${ }^{2}$

A tecnologia da escrita não é algo meramente exterior, de que o homem faz uso sem deixar se envolver. Torna-se parte da estrutura mental, não só no que se refere à própria escrita, mas também à oralidade. Um homem letrado não pensa e fala apenas por um impulso natural. Pois a escrita constitui seu ato de falar e permeia todo o processo de pensamento. A escrita não tem o papel de simplesmente retratar e espelhar a fala, mas impõe um outro paradigma, de tal forma que o pensamento crítico só se torna realizável em virtude da sua própria existência. Cabe ressaltar que se por um lado Platão censura a escrita, por outro também reconhece que é um caminho sem volta. A escrita é um instrumento poderoso que adentrou e tomou conta do nosso intelecto. A crítica de Platão à antiga tradição homérica é uma consequência inevitável da sua teoria do conhecimento, sobretudo pelas ideias platônicas, que expressam uma rejeição inconsciente à antiga tradição poética e oral.

As ideias platônicas seriam, então, segundo Ong, idênticas àquilo que a escrita é por natureza. As características da ideia coincidem com o universo da escrita. A estabilidade e a separação do mundo comum definem tanto a escrita quanto as ideias platônicas. Para Ong, Platão não elaborou isso de forma proposital, foi uma atitude involuntária em resposta à crise da tradição homérica oral, o que deu origem a uma nova concepção sobre a linguagem, livre dos paradigmas do passado. Podemos aqui destacar dois argumentos que dificultam a interpretação da crítica de Platão à escrita: a expulsão dos poetas na República e a semelhança das ideias com a linguagem escrita. Ao excluir o poeta da sua cidade ideal, no Livro X da República, Platão de certa forma rompe com toda uma tradição fundada em saberes verbais. Na cidade platônica ideal, as únicas formas de poesia acolhidas são o cântico aos deuses e o panegírico solene aos homens exemplares. As demais manifestações poéticas são julgadas corrompíveis e

\footnotetext{
${ }^{2}$ Walter Ong, Oralidade e cultura escrita: a tecnologização da palavra, 1998, p. 95 a 96.
} 
prejudiciais ao cultivo da excelência moral. ${ }^{3} \mathrm{~A}$ crítica à poesia trata exatamente do objeto da poesia, que está - assim como o da pintura - no nível mais inferior de relação hierárquica com as ideias. $\mathrm{O}$ termo mímesis (imitação) é definido no Livro III como o gênero literário no qual o poeta narra em primeira pessoa interpretando uma personagem. Esse gênero literário diverge da narrativa em terceira pessoa (áple diégesis), uma forma poética mais simples que a mímesis, porque o poeta não precisa assumir um papel, mas se refere à personagem com o devido distanciamento. ${ }^{4}$ As obras dos poetas têm como matéria a maneira como as coisas se apresentam aos sentidos. São, na prática, a aparência de uma aparência, e, portanto, duas vezes distantes da realidade. Os produtos manufaturados elaborados pelos artesãos estão acima da poesia e da pintura, participam mais do ser e são apenas uma aparência, ao contrário da poesia que é a aparência de uma aparência. $O$ termo idea está associado à palavra latina video, ambas relacionadas a algo que é percebido pelos olhos. A ideia conserva os atributos de um objeto que só pode ser visto, sem ser percebido pelos demais sentidos, assim como a escrita que se comunica com o leitor mediante a visão. No âmbito oral as palavras só ganham significado quando inseridas em um contexto vivo. A escrita, longe disso, possui o sentido das palavras concentrado na própria linguagem. Ong defende que a separação das ideias do mundo comum foi, na realidade, uma saída encontrada para repelir os resquícios de oralidade provenientes da antiga tradição poética. Sendo assim, uma indicação de que, para Platão, a cultura escrita veio para fincar suas bases e suceder a cultura homérica.

Thot é essencialmente o deus da escritura, o secretário de Ra e dos nove deuses, hierogramático e hipomnetógrafo. Ora, é mostrando, nós o veremos, que o phármakon da escritura era bom para a hupómnésis (rememoração, recoleção, consignação) e não para a mnèmè (memória viva e conhecedora) que Thamous, no Fedro, denuncia seu pouco valor. ${ }^{5}$

Em La pharmacie de Platon, Derrida faz uma interpretação da simbologia do deus Thoth, desde a origem e seu significado místico no contexto da mitologia

\footnotetext{
${ }^{3}$ Cf. Platão, A República, 2012, 607a.

${ }^{4}$ Cf. Ibidem, 392d.

${ }^{5}$ Jacques Derrida, A farmácia de Platão, 2005, p. 36.
} 
egípcia até seu aparecimento como inventor da escrita no diálogo Fedro. Interpreta a figura do deus como uma espécie de mago ou médico que apresenta a sua invenção como um remédio para o esquecimento. Na narrativa de Platão, o rei Tamuz contesta veementemente a confiança de Thoth nos poderes da escrita e é categórico na rejeição da proposta, argumentando que a escrita seria, na realidade, um veneno que enfraqueceria gradualmente a memória. Derrida argumenta que a função terapêutica da escrita precisa ser compreendida no âmbito da hypómnésis e não da mnèmè, isto é, como um instrumento auxiliar e não como fundamento no qual a memória está assentada. A memória (mnèmè) na realidade é um sintoma da reminiscência (anamnese), ou seja, o reconhecimento das ideias que a alma contemplou antes de encarnar no corpo. Portanto, para Platão, a memória não resulta em conhecimento efetivo, mas apenas em imagens distanciadas das ideias antes contempladas. "A mneme, que é a memória das ideias vistas pela alma antes de nascer, se configura necessariamente em forma de logos, e, nesse sentido, é um traço da origem ausente"6. Trabattoni analisa a interpretação de Derrida sobre a distinção presente no diálogo Fedro entre mnèmè e hypomnesis. A posição de Tamuz de pessimismo em relação à escrita não deve ser simplesmente entendida como um enaltecimento da oralidade.

Qual é, em primeiro lugar, o motivo pelo qual Tamuz culpa o presente recebido de Thoth [...]? Tamuz, na realidade, não faz nenhum aceno ao que pode ensinar-se oralmente e ao que pode (ou não) ensinar-se por escrito. $O$ que ele opõe à escrita não é uma doutrina oral, mas um saber interno e uma consciência ("do íntimo, espontaneamente"), diverso e distinto do saber externo produzido pela escrita. ${ }^{7}$

O que está em questão é a compreensão de que o conhecimento se manifesta no âmago da alma e, portanto, permanece alheio ao caráter superficial da escrita. Trabattoni esclarece o verdadeiro sentido do desafio de Tamuz ao deus

\footnotetext{
${ }^{6}$ Franco Trabattoni, Jacques Derrida e le origini greche del logocentrismo, 2004, p. 565, tradução minha: "La mneme, cioè il ricordo delle idee viste dall'anima prima di nascere, si configura necessariamente in forma di logos, ed in questo senso è traccia dell'origine assente".

${ }^{7}$ Franco Trabattoni, La verità nascosta: oralità e scrittura in Platone e nella cultura greca clássica, 2005, p. 87, tradução minha: "Qual è, in primo luogo, il motivo per cui Thamous biasima il dono ricevuto da Theuth [...]? Thamous in realità non fa nessun accenno a ciô che si può insegnare oralmente e a ciô che si puô (o non si puô) insegnare per iscritto. Ciô che egli contrappone alla scrittura non è una docttrina orale, ma un ssapere e una consaspevolezza interni ("dall'intimo, spontaneamente"), diversi e distinti dal sapere esterno prodotto dalla scrittura".
} 
Thoth, a crítica do monarca ao invento do deus não possui o objetivo de exaltar a oralidade em detrimento da escrita, mas chamar atenção para uma realidade mais profunda.

Para elucidar melhor o sentido da crítica platônica à escrita, no diálogo Fedro, será preciso situar o contexto onde está inserida. $\mathrm{O}$ mito de Thoth aparece na parte final do diálogo, na qual Sócrates e Fedro discutem acerca da natureza da retórica e sobre em que consiste escrever um belo discurso: "[...] sabes quais são as condições necessárias para que, já os discursos, já as ações, sejam agradáveis aos deuses?"8 Sócrates lança o mito como uma possibilidade de responder a essa pergunta. Um bom discurso não busca agradar aos homens, mas aos deuses, verdadeira fonte da sabedoria. O problema que Sócrates coloca é o seguinte: seria possível haver uma arte retórica livre da necessidade do conhecimento da verdade? Para Sócrates, isso seria absurdo. Mas a relação de proximidade com a verdade não é o único fator determinante para que o orador obtenha sucesso na persuasão. São dois fatores conjuntos, tanto conhecer o objeto sobre o qual se discursa quanto saber se expressar com eloquência. Esse é o verdadeiro retórico, definido por Sócrates, instruído na verdade e hábil nos discursos. Porém, cabe nesse ponto levantar um questionamento: por que Platão retira a legitimidade da escrita enquanto instrumento propício ao aperfeiçoamento da arte retórica?

No início do século XIX, Schleiermacher seguiu uma linha de interpretação cujo objetivo era se dedicar exclusivamente aos diálogos e desvincular a imagem de Platão dos desdobramentos posteriores para, então, afastá-lo do vínculo com os discípulos da Academia. ${ }^{9} \mathrm{O}$ objetivo central era dar autonomia à filosofia de Platão para compreendê-lo na sua singularidade. Entretanto, essa tendência acaba ignorando um aspecto vital da filosofia de Platão, e que passou a ser conhecido, pelas escolas de Tübingen e de Milão, como as doutrinas não escritas. O próprio Nietzsche, já no final do século XIX, recorre ao diálogo Fedro para fazer críticas a Schleiermacher, por sustentar uma leitura

\footnotetext{
${ }^{8}$ Platão, Fedro, 1989, 274c.

${ }^{9}$ Cf. Schleiermacher, Introdução aos diálogos de Platão, 2002.
} 
equivocada sobre a pedagogia de Platão ao supor que o aprendizado da filosofia fosse preponderantemente vinculado à escrita. ${ }^{10}$ No século $\mathrm{XX}$, a tese de Schleiermacher começa a ser contestada por eruditos da Escola de Tübingen e posteriormente por outros estudiosos que reforçaram ainda mais essa nova abordagem, esotérica, sobre a filosofia de Platão. A problemática se desenvolve, inicialmente, como uma tentativa de explicar o motivo da discrepância entre o que Aristóteles afirma sobre a filosofia de Platão nos Livros XIII e XIV da Metafísica em relação ao conteúdo dos próprios diálogos. A partir disso muitos estudos foram desenvolvidos com o objetivo de demonstrar que o pensamento de Platão não pode ser reduzido apenas ao que aparece no interior dos diálogos. ${ }^{11}$ Para Schleiermacher, os diálogos de Platão são um caminho para a iniciação, de tal forma que o conjunto dos textos figuram em um segundo plano (após a dialética e o aprendizado oral) como um caminho seguro para que os leigos possam ser iniciados no estudo da filosofia. Reale argumenta que a escrita, no circuito da Academia, exercia uma função de meramente instruir os discípulos que já eram iniciados e que, portanto, possuíam um conhecimento prévio. As doutrinas não escritas são ensinamentos secretos que não devem ser conhecidos por estranhos, os princípios supremos da filosofia que eram intencionalmente ocultados nas entrelinhas dos diálogos.

De uma série de indícios convergentes que se encontram no Fedro inferese claramente em que consistem exatamente "as coisas de maior valor" [...] que o filósofo não confia aos escritos. [...] das quais unicamente depende a solidez, a clareza e a completude do raciocínio e que, em última análise coincidem, no sentido mais elevado, com os primeiros e supremos Princípios. Mas, enquanto Platão no Fedro diz isso por meio de vários tipos de acenos, no excursus contido na Carta VII afirma-o de maneira mais explícita. ${ }^{12}$

Para caminhar na direção de uma compreensão mais ampla sobre o assunto, faz-se necessário analisar a Carta Sétima, uma das últimas cartas escritas

\footnotetext{
${ }^{10}$ Cf. Nietzsche, Gesammelte Werke: vierter band, 1953, p. 370.

${ }^{11}$ Cf. Robin, La Théorie platonicienne des idées et des nombres d'après Aristote, 1908; Stenzel, Zahl und Gestalt bei Platon und Aristoteles, 1924; Krämer, Arete bei Platon und Aristoteles: Zum Wesen und zur Geschichte der platonischen Ontologie, 1959; Gaiser, Das Platonbild, 1969; Findlay, Plato, the writen and unwritten doctrines, 1974; Reale, Per una nuova interpretazione di Platone, 1984; Szlezák, Platon und die Schriftlichkeit der Philosophie, 1985; entre outros não mencionados.

${ }^{12}$ Giovanni Reale, Platão, 2007, p. 17.
} 
por Platão em um período após suas três viagens à Sicília. E, assim como a parte final do Fedro, é reconhecida por fazer uma crítica à escrita. Na primeira viagem, Platão vai à Siracusa para tentar educar Dionísio I, pai de Dionísio II. No entanto, a tentativa resulta em fracasso e o tirano expulsa Platão, que acaba vendido como escravo. A sorte de Platão foi que um amigo, Anicérides, comprou-o e levou-o de volta à Atenas. ${ }^{13} \mathrm{~A}$ segunda viagem ocorre sob a influência de Díon, uma personagem importante na política de Siracusa. Sendo admirador de Platão, ele incentiva o novo tirano a convocá-lo. Platão aceita e parte para uma segunda tentativa de empreender o projeto da sua República, de educar um governante como filósofo. Devido a conflitos políticos, Díon acaba exilado, o que fez com que Platão desistisse e retornasse finalmente para Atenas. ${ }^{14}$ Platão narra os acontecimentos sobre sua segunda tentativa de desempenhar a função de mentor na corte de Dionísio II, um tirano que se dizia propenso ao estudo da filosofia. A terceira viagem, assim como as duas anteriores, foi uma decepção. ${ }^{15}$ Platão introduziu algumas lições de filosofia, superficiais, para ver como o tirano reagiria. Ao invés de aguçar seu interesse e ter a lucidez de que seria preciso para se aprofundar mais nas questões filosóficas, o tirano escreveu um grande apanhado das lições que havia recebido, considerando assim que já obtinha tudo aquilo que os ensinamentos de Platão poderiam oferecer. Um espírito realmente inspirado pela filosofia jamais pensaria dessa forma. Dionísio estava mais preocupado em ostentar o status de filósofo do que se dedicar verdadeiramente à filosofia. A partir desse relato, Platão apresenta a tese de que o conhecimento filosófico se efetiva exclusivamente no interior da alma.

[...] não há nem nunca haverá uma obra minha que trate destes temas; não podem, com efeito, serem precisados como se faz em outras ciências, senão que após uma longa convivência com o problema e após haver intimidade com ele, de repente, como a luz que salta da faísca, surge a verdade na alma e cresce espontaneamente. Sem dúvida, tenho a certeza de que, tanto por

\footnotetext{
${ }^{13}$ Cf. Diógenes Laércio, Vidas e doutrinas dos filósofos ilustres, livro III, 19-20.

${ }^{14}$ Cf. Ibidem, Livro III, 21.

${ }^{15}$ Cf. Ibidem, Livro III, 23.
} 
escrito como pela fala, ninguém poderia expor tais matérias melhor do que $\mathrm{eu}^{16}$

O aprendizado da filosofia requer uma predisposição pessoal do iniciado, que não encontra o saber em regras e manuais, mas no seu íntimo, no interior da própria alma, único reduto onde se encontra o verdadeiro conhecimento. A conduta de Dionísio II revela uma postura tipicamente não filosófica, visto que o tirano não se deu conta da magnitude dos ensinamentos de Platão. Preferiu a ostentação à verdadeira filosofia, querendo se aproveitar das instruções para se exibir, apenas com o intuito mórbido de ganhar prestígio.

Para esclarecer sua crítica à escrita, Platão analisa as ferramentas do conhecimento. ${ }^{17}$ Podemos considerar cinco categorias do conhecimento, começando por três níveis básicos: o nome (ónoma), a definição (lógos) e a imagem (eídolon). O nome é um termo convencional que designa determinado objeto, assim como o círculo, que Platão usa como exemplo. A definição explica a natureza do objeto e está, portanto, um grau acima do anterior. Em terceiro lugar, vem a imagem que é uma representação visual do objeto. Segundo Platão, o conhecimento não se encontra em nenhuma dessas instâncias, mas em uma categoria acima, na qual se manifesta o conhecimento real (epistéme). 0 conhecimento é o que mais se aproxima da ideia (eidos), uma proximidade relativa, porque o conhecimento não ascende até a ideia, não toca nas suas extremidades e se mantém a uma distância intransponível. A condição da epistéme (conhecimento) é limitada pelo vínculo da alma ao corpo, enquanto permanece encarnada, a alma não vislumbra a contemplação do eidos (ideia). As ideias, conforme Platão revela no diálogo Fedro, são contempladas em um momento único e específico, antes da alma encarnar em um corpo. ${ }^{18}$ Platão

\footnotetext{
${ }^{16}$ Platón, Cartas, 1992, 341d, tradução minha: “[...] no hay ni habrá nunca una obra mía que trate de estos temas; no se pueden, en efecto, precisar como se hace con otras ciencias, sino que después de una larga convivência con el problema y después de haber intimado con él, de repente, como la luz que salta de la chispa, surge la verdad en el alma y crece ya espontáneamente. Sin duda, tengo la seguridad de que, tanto por escrito como de viva voz, nadie podría exponer estas matérias mejor que yo".

${ }^{17}$ Cf. Ibidem, 342a-d.

${ }^{18}$ Cf. Ibidem, 1989, 249b-c.
} 
observa que é impossível acessá-la plenamente, pois o conhecimento é sempre limitado. Trabattoni analisa a Carta VII como uma referência essencial para compreender a condição de fragilidade inerente à própria linguagem: "[...] nenhum desses quatro elementos [...] corresponde ao quinto, ou seja, à coisa em si mesma. [...] não existe nenhum discurso capaz de exprimir a coisa em seu estado puro, como ela é em si e por si”. ${ }^{19}$ A escrita é, então, um instrumento ineficiente para o exercício da arte retórica. Embora a oratória certamente seja mais prolífica do que a escrita no que concerne à performance discursiva. "Para Platão, a obra escrita engendra em seu leitor tão somente um falso conhecimento, uma verdade pronta; somente o diálogo vivo é formativo. [...] É nas almas, e não nos livros, que é necessário semear com a ajuda da fala" ${ }^{20}$ Hadot comenta, no prefácio à L'enseignement oral de Platon, sobre a teoria do conhecimento de Platão - a partir de uma abordagem dos diálogos Fedro, A República e a Carta VII - e identifica a primazia do diálogo vivo como elemento mais frutífero e efetivo do que a escrita no esforço em direção ao conhecimento da verdade. Platão reconhece a importância de exercitar-se nos três primeiros níveis, antes de dispor do conhecimento real. Apesar da escrita ser considerada um mero apetrecho sem tanta relevância, tal convicção não suscita um despojamento absoluto do valor da escrita enquanto exercício de aperfeiçoamento retórico. ${ }^{21}$ Contudo, nem o nome, nem a definição, nem a imagem e nem o próprio conhecimento tem a competência de produzir a persuasão. Ao se prender a isso, o orador se transforma em uma presa fácil e acaba refutado pela impossibilidade de fixar o conhecimento nos quatro domínios mais elementares. Se a ideia é impenetrável e o conhecimento não provoca a refutação, qual é o objeto da retórica? A retórica lida com a alma e com a maneira pela qual ela interage com o conhecimento. Cabe nesse ponto ressaltar o valor que Platão dá à vivência, ao árduo empreendimento que o trabalho filosófico exige. É preciso que esfreguemos (tribomena; Cf. 344b),

\footnotetext{
${ }^{19}$ Franco Trabattoni, Platão, 2012, p. 97.

${ }^{20}$ Marie-Dominique Richard, L'enseignement oral de Platon, 2005, p. 11, tradução minha: "Car pour Platon, I'reuvre écrite n'engendre chez son lecteur qu'un faux savoir, une vérité toute faite; seul le dialogue vivant est formateur. [...] C'est dans les âmes, et non dans les livres, qu'il faut semer a I'aide de la parole".

${ }^{21}$ Cf. Marcus Reis, O Fedro e a escrita, 2008, p. 85.
} 
não só os instrumentos que temos em nossas mãos (definições de nomes, imagens e impressões), mas também que debatamos e pensemos amplamente sobre eles.

Platão considera que é necessário haver uma predisposição natural, porque a filosofia requer um momento oportuno e uma intensa intimidade com o assunto. O caráter ético é crucial para a prosperidade do iniciado, uma vez que para que ele se deixe persuadir, é indispensável desfrutar de uma mente benigna e livre de vaidades. Ao criticar a escrita, Platão chama atenção para um tipo de experiência vital que transforma o modo de vida do filósofo. Nem o exercício da escrita e nem os discursos orais são capazes de nos conduzirem ao verdadeiro conhecimento. $O$ único caminho é confiar à própria alma, no âmago do próprio ser, a busca pela verdade, escondida e confinada no interior de si mesmo. A crítica de Platão à escrita acaba por se estender também ao mundo oral. Podemos dizer que os discursos orais estão mais próximos da vivência que a filosofia exige, mas o conhecimento não se realiza mediante o diálogo. O conhecimento surge, então, quando a partir desse esfregar surge uma faísca dentro da alma, único lugar onde se desvelam vestígios da coisa mesma, objeto puro do conhecimento.

\section{Montaigne e a arte de conversar}

Os Ensaios de Montaigne foram concebidos como uma espécie de monólogo, um discurso em primeira pessoa, no qual o autor estabelece um diálogo consigo mesmo. ${ }^{22}$ Não que sejam apenas um modesto falar com si próprio, pois o ensaio possui um estilo versátil, que instaura múltiplas interlocuções, com diversos autores e leitores. Burke analisa os Ensaios e identifica quatro interlocutores com quem Montaigne se comunica: "Montaigne escreveu com um estilo deliberadamente oral, conversacional. [...] Ele estabelecia conversação ou diálogo com quatro interlocutores: com o outro, consigo mesmo, com escritores

\footnotetext{
${ }^{22}$ A tradução dos Ensaios que será nossa referência é a de Sérgio Milliet (1972), mas as citações serão indicadas segundo os parâmetros da edição do texto original de Pierre Villey (1924).
} 
anteriores e com futuros leitores". ${ }^{23}$ Há uma polissemia peculiar ao discurso ensaístico que confronta autores variados mediante um uso abundante de citações. Montaigne imagina, a princípio, uma conversa expressa do autor consigo mesmo, assim como um diálogo do autor com um possível leitor imediato. Tais interlocutores são, supostamente, pessoas íntimas de Montaigne, amigos e familiares, como o próprio revela no prefácio Au Lecteur. ${ }^{24}$ Ele estabelece, além disso, de forma requintada, diálogos com autores antigos, ao criar um espaço cativo onde ecoam as grandes vozes do passado, referências e alusões aos poetas e filósofos que marcaram a tradição ocidental. $O$ quarto e último dos interlocutores é de certa forma o menos tangível, uma espécie de projeção dos futuros leitores que conhecerão a obra na posteridade. Isso significa que a maneira como o autor se enxerga no cenário histórico do seu tempo está de certa forma intimamente ligada à maneira como o autor se lança para o futuro. Montaigne escreveu no final do século XVI, um período em que a influência da filosofia aristotélica ainda exercia um imenso protagonismo e a sua obra é uma expressão clara de ruptura com a tradição. O estilo do tratado característico dos textos de Aristóteles foi extremamente influente, sendo recebido pelos teólogos escolásticos como o modelo básico para a escrita filosófica. Os Ensaios são uma clara expressão de recusa do estilo predominante em boa parte dos filósofos cristãos. O ensaísta delineia um estilo tão refinado, a ponto de estabelecer canais de comunicação variados, criando pontes com autores de diversas épocas. A discussão com os autores antigos e a projeção dos futuros leitores giram em torno do mesmo eixo. Montaigne filosofa na medida em que dialoga com grandes personagens da filosofia, como Sêneca e Plutarco, autores pelos quais o ensaísta nutria um enorme fascínio.

Se por um lado Platão escreveu diálogos estruturados como discussões reais, por outro, Montaigne inventou uma forma de transmitir a atmosfera da

\footnotetext{
${ }^{23}$ Peter Burke. Montaigne y el arte del diálogo, 2009, p. 5, tradução minha: "Montaigne escribía con un estilo deliberadamente oral, conversacional. [...] Él entablaba conversación o diálogo con cuatro interlocutores: con el outro, consigo mismo, con escritores anteriores y con futuros lectores".

${ }^{24} \mathrm{Cf}$. Michel de Montaigne, Essais (Au Lecteur), 3A.
} 
oralidade para o universo da escrita, sem precisar criar o cenário de um diálogo como artifício para representar a fluência do mundo oral. "[A] Não busco nos livros senão o prazer de um honesto passatempo; e nesse estudo não me prendo senão ao que possa desenvolver em mim o conhecimento de mim mesmo e me auxilie a viver e morrer bem". ${ }^{25}$ A leitura, sempre que em doses elevadas, maçante e aborrecida, pode ser nociva ao espírito do leitor. Nessa passagem do ensaio Des Livres (II, 10), Montaigne faz uma crítica explícita à escrita, que deve ser perpetrada meramente para o divertimento pessoal. Não deveríamos tratar a escrita com seriedade, salvo no que concerne ao conhecimento de si mesmo e à arte de bem viver. Montaigne ressalta o valor da vivência e da experiência individual para se alcançar um modo de vida genuinamente filosófico. De nada vale se perder em meio a incansáveis leituras, se se descuida da própria conduta. Uma boa conversa, ao vivo e a cores, seria então imprescindível para elevar o vigor do espírito: "[B] A frequentação dos livros é uma atividade calma e fraca, que não entusiasma, enquanto a conversação ensina e exercita ao mesmo tempo". ${ }^{26} \mathrm{~A}$ intensidade e a vivacidade de uma discussão real fomentam a aprendizagem e exercitam a habilidade oratória. Não se aprende a discursar bem em público lendo as linhas mortas de um livro. Em De l'art de conferer (III, 8), Montaigne defende a ideia de que dialogar e suportar as adversidades de uma conversa concreta é o único caminho que conduz ao desenvolvimento pleno das habilidades oratórias.

Os Ensaios são um texto essencialmente assistemático em que não há uma estrutura rígida. Montaigne não aspira chegar a conclusões definitivas, seus ensaios dão sempre a impressão de que fica alguma coisa pendente, não havendo um término ao fim de cada ensaio. Isso ocorre porque o ensaio é um estilo elaborado para reproduzir as características do mundo oral no interior da escrita. Possui a desorganização e a mesma fluidez de uma conversa factual. Embora não estivesse mais preocupado com a eloquência do texto do que com a sua

\footnotetext{
${ }^{25}$ Michel de Montaigne, Essais, II, 10, 409A.

${ }^{26}$ Ibidem, III, 8, 923B.
} 
espontaneidade, Montaigne tinha plena consciência dos efeitos causados nos leitores pelo estilo da sua escrita. Um texto extravagante e rico em significado, forte o bastante para resistir às más interpretações.

$\mathrm{Na}$ série das oposições e das antíteses vigorosas em que Montaigne inscreve suas preferências, o fazer silencioso prevalecera de início contra o arrebatamento fútil do dizer. Mas o dizer, condição de toda pintura de si, não permanece objeto de uma recusa inapelável. Mais uma vez, na ordem da linguagem, Montaigne estabelece uma nova oposição, que lhe permite professar seu gosto pela palavra viva, contra a forma imobilizada do escrito. Contudo, o escrito será finalmente aceito - escolha que se justifica pela preferência que Montaigne experimenta com relação a uma progenitura espiritual, mais fiel e semelhante que qualquer descendência segundo a carne. $^{27}$

De acordo com Starobinski, a inclinação de Montaigne pela expressão oral se consolida, nos Ensaios, pela harmonização com a letra escrita. A imagem viva de si mesmo, construída por intermédio de componentes fragmentários, ganha uma unidade no todo da obra, que transcende as circunstâncias efêmeras que a produziram. A pintura de si - definição original do estilo montaigniano - gera, enfim, uma obra-prima, uma imagem completa do autor, que ultrapassa as narrativas multifacetadas que compõem a formação dos Ensaios.

Quando escrevo, não recorro nem aos livros nem à lembrança que deles tenha, de medo que influam na minha maneira de escrever, sem contar que os bons autores me desesperam e desanimam. Sou como aquele pintor, que, tendo representado uns galos de um modo pouco feliz, proibia a seus ajudantes de trazerem galos de verdade ao atelier, a fim de evitar qualquer comparação. ${ }^{28}$

No capítulo Sur des vers de Virgile (III, 5), nota-se uma revelação sobre o método praticado no ato de escrever. Montaigne se desvencilha dos livros para se inspirar ao máximo em si mesmo, dando vazão à imaginação e à originalidade do pensamento. Se permitisse a intervenção externa de textos de outros autores, perderia a fluência das suas ideias e se manteria submetido à inércia da escritura. O segredo de Montaigne parece ser escrever esquecendo que se está escrevendo, para dessa forma transmitir suas palavras despretensiosamente, com naturalidade e franqueza. A metáfora do pintor explica com precisão o

\footnotetext{
${ }^{27}$ Jean Starobinski, Montaigne em movimento, 1992, p. 40.

${ }^{28}$ Michel de Montaigne, Essais, III, 5, 874B.
} 
procedimento montaigniano: mesmo reconhecendo a má qualidade da ilustração do galo na tela, o artista prefere continuar seu lavor com seus próprios recursos, dependendo apenas da sua criatividade, para que o resultado da obra exprima a realidade íntima do seu ser. Montaigne pinta a si mesmo propositadamente como objeto da sua obra.

[...] há textos escritos que deixam marcas vivas de uma situação oral prévia, e inclusive textos que não deixam de ser, apesar de sua condição escrita, expõem um repentino diálogo com supostos leitores. Nesse sentido, é destacável a brilhante leitura que Peter Burke faz dos Ensaios de Montaigne em chave de diálogo. A explicação dos Ensaios a partir de uma forma de comunicação propriamente oral, se bem explicitamente apresentada como tal, supõe, sobretudo, estabelecer uma sorte de conversações com o leitor (real ou implícito) e com os próprios autores precedentes (Burke destaca o uso criativo da citação alheia como um indício desse diálogo, ideia devida ao teórico russo Bakhtin). Esse diálogo constante entre autor e leitor comporta certas condições, entre as que cabe destacar o predomínio do eu (a representação do autor como tema mesmo da obra no é um feito casual ou acessório para compreender a natureza dialógica dos Ensaios) ou a deliberada ausência de uma ordem ou esquema na hora de abordar os diferentes assuntos que vão sendo tratados. ${ }^{29}$

Jurado comenta sobre a importância do $e u$, da referência às próprias experiências de vida, como ponte para os diálogos que o autor pretende desenrolar. Os Ensaios, além de refletirem toda a dinâmica de uma conversa autêntica, seguem o preceito de que o autor é o tema central da sua obra. Quando cita outros autores, Montaigne visa nada mais nada menos que compreender a si próprio. Jamais obteremos uma noção histórica linear da filosofia a partir dos Ensaios. Ao invés disso, a citação criativa tece um diálogo complexo com os antigos autores da filosofia. Montaigne está sempre disposto a mudar de ideia,

\footnotetext{
${ }^{29}$ Francisco Jurado, La oralidad escrita del saber: Aulo Gelio e Michel de Montaigne, 2010, p. 74 a 75, tradução minha: "[...] hay textos escritos que dejan huellas vivas de una situación oral previa, e incluso textos que no dejan de ser, a pesar de su condición escrita, acicate para un ágil diálogo con supuestos lectores. En este sentido, es destacable la brillante lectura que Peter Burke ha hecho de los Ensayos de Montaigne en clave de diálogo. La explicación de los Ensayos a partir de una forma de comunicación propiamente oral, si bien presentada explicitamente como tal, supone, sobre todo, establecer uma suerte de conversación con el lector (real o implícito) y con los propios autores precedentes (Burke señala el uso creativo de la cita ajena como un indicio de ese diálogo, ideia deudora del teórico ruso Bajtin). Este diálogo constante entre autor y lector conlleva ciertas condiciones, entre las que cabe destacar el predominio del yo (la representación del autor como tema mismo de la obra no es un hecho casual o accesorio para comprender la naturaleza dialogística de los Ensayos) o la deliberada ausencia de un orden o esquema a la hora de abordar los diferentes assuntos que se van tratando".
} 
não se apega demais a uma única doutrina e faz sempre questão de evidenciar sua autocrítica. Se ele é o ponto central dos Ensaios, então cabe se apresentar com inteira naturalidade e descontração.

Uma característica surpreendente em Montaigne é a falta de compromisso com a ordem, cada ensaio segue um fluxo incerto e é concluído sem muita coesão. Os textos ensaísticos deixam a impressão de estarem sempre inacabados, não há um desfecho e nem mesmo um ponto de partida pontuais. A obra como um todo parece não possuir uma unidade temática e cada um dos três livros abriga assuntos variados. Os capítulos isolados são os núcleos temáticos dos Ensaios, embora a digressão seja um dos princípios fundamentais que guiam a escrita ensaística. Montaigne é indefinível, possui muitas faces, não procura verdades, mas filosofa estimulando interrogações e não proclamando respostas. Prefere a concisão na simplicidade das palavras e detesta as artimanhas do discurso retórico. Os recursos retóricos são contraproducentes, porque desviam a essência das palavras, buscando supervalorizá-las. Conforme atesta Tournon, os escritos são, para Montaigne, apenas um meio de estimular a imaginação do leitor, de modo que por si mesmo ele navegue pelas suas fantasias e encontre um sentido livre dos ditames da palavra escrita:

Como que destacadas do pensamento (as "coisas" = as ideias), as "palavras" não são mais do que índices aproximativos; e toda retórica destinada a valorizá-la, como paliativo artificial para suas insuficiências, teria por defeito, paradoxalmente, restringir os recursos da comunicação, escamoteando os subentendidos. A concisão é, pois, a qualidade primordial de uma linguagem natural. ${ }^{30}$

Para Montaigne o conhecimento erudito das letras não se traduz em uma forma de sabedoria palpável. A aquisição do conhecimento precisa refletir na maneira de viver do filósofo. Uma devoção pedante às letras não ensina a bem viver e nem a cultivar bons pensamentos. São as experiências ordinárias que desvendam o enigma da vida e não o estudo das letras.

Será a licença de nossa época, uma desculpa para que ache igualmente tediosos, exaustivos os diálogos do próprio Platão? Lamento o tempo que

${ }^{30}$ André Tournon, Montaigne, 2004, p. 189. 
perde, em vãs interlocuções preparatórias, um homem que tinha tanta coisa importante a dizer. Minha ignorância justificará sem dúvida o desprazer que me causa seu estilo. ${ }^{31}$

Montaigne revela, no capítulo Des Livres (II, 10), sua insatisfação com o estilo dialogal de Platão. Julga os preâmbulos e interlúdios de Sócrates enfadonhos, porque são rodeios irrelevantes que servem meramente para preparar o terreno para o que realmente é importante. Circulavam muitos diálogos no contexto do século XVI, o que mostra que esse estilo era uma referência literária corrente durante a Renascença.

Ademais, os ensaios foram escritos em um momento em que muitos diálogos - sem mencionar obras de teatro - apareciam impressos na Itália, França, Inglaterra e Espanha. Famosos exemplos espanhóis desse período incluem De los nombres de Cristo, de Fray Luis de León (1583), e Diálogos de medallas (1587), de Antonio Agustin. Igualmente, em seu ensaio Dos livros, Montaigne comete o que chama o <<sacrilégio>> de julgar os diálogos de Platão como prolixos e tediosos. Portanto, pode parecer que o autor rechaçava conscientemente a forma de diálogo com a finalidade de construir um novo gênero literário. ${ }^{32}$

Tendo como referência o trecho supracitado, Burke presume que os Ensaios foram produzidos como um estilo de escrita inovador, com o objetivo de ultrapassar os paradigmas da forma dialógica. Tal proposição é digna de nota. $\mathrm{O}$ ensaio expandiu as fronteiras da escrita filosófica e talvez seja atualmente um dos principais parâmetros estilísticos. A dificuldade que permanece é a especulação sobre a real intenção de Montaigne. Os Ensaios foram escritos tendo como horizonte o propósito fundamental de superar o diálogo? Ou a produção do estilo foi apenas uma consequência acidental que não foi prevista pelo seu autor? Talvez seja uma pergunta sem respostas.

\footnotetext{
${ }^{31}$ Michel de Montaigne, Essais, II, 10, 414AC.

${ }^{32}$ Peter Burke. Montaigne y el arte del diálogo, 2009, p. 5, tradução minha: "Es más, los ensayos se escribieron en un momento en que muchos diálogos - por no mencionar obras de teatro aparecían impresos en Italia, Francia, Inglaterra y España. Famosos ejemplos españoles de este período incluyen De los nombres de Cristo, de Fray Luis de León (1583), y Diálogos de medallas (1587), de Antonio Agustin. Igualmente, en su ensayo De los libros, Montaigne comete lo que llama el "sacrilégio" de describir los famosos diálogos de Platón como prolijos y aburridos. Por lo tanto, puede parecer que el autor rechazaba conscientemente la forma del diálogo con el fin de construir un nuevo género literário".
} 


\section{Conclusão}

De um lado temos Platão, que representa o estilo de escrita empenhado em reproduzir uma discussão realista. As palavras nos diálogos platônicos não se referem a algo que ele mesmo diz e não podem ser referidas aos seus próprios pensamentos (com exceção das Cartas, onde Platão escreve em primeira pessoa). Na maioria dos diálogos, Sócrates aparece como protagonista. O que nem sempre acontece, como no Parmênides, por exemplo, texto em que Sócrates aparece como mero coadjuvante. Isso dificulta ou, até mesmo em alguns casos, impossibilita o discernimento daquilo que Platão realmente acreditava. Os discursos manifestos nos seus diálogos têm em si uma referência simples e objetiva: a respectiva fala das personagens, que possivelmente teria acontecido na vida real. Do outro lado, temos Montaigne, filósofo atípico e inovador, que idealizou uma nova forma de conceber a escrita. Seu estilo é meditativo e em primeira pessoa. Esse monólogo do autor consigo mesmo permite a composição de uma variedade de diálogos, que nem sempre estão declarados explicitamente, por isso é indispensável o cuidado para conseguir ouvir o diálogo que se esconde por trás do que aparenta ser um monólogo trivial.

Montaigne está muito próximo de Platão no que concerne ao pensamento crítico sobre a escrita. Ambos deram primazia à oralidade e alertaram sobre os malefícios provocados pela escrita e as semelhanças não param por aí. Enalteceram o valor da vivência como essencial ao estudo da filosofia. 0 propósito da filosofia, tanto para um como para outro, é promover o conhecimento de si mesmo. O conhecimento de si é motivado pelo propósito de preparar a alma para a morte e guiar o filósofo na direção de uma vida virtuosa. Ambos estão preocupados em definir a filosofia como uma forma de vida. E nisso, de fato, não há discrepância entre os autores.

A diferença entre Montaigne e Platão, no que diz respeito à temática da oralidade e da escrita, reside no fato de Montaigne ser mais otimista com relação aos benefícios provenientes da oralidade. Para o ensaísta, o exercício de uma boa 
conversa desenvolve e fortalece o espírito. Platão também admitiu a importância de dialogar e discursar em público como uma forma mais segura de treinar e aprimorar as habilidades oratórias. Mas acabou por renunciar à oralidade como critério para o autêntico conhecimento, que na sua concepção sucede no âmago da alma do iniciado, impossível de ser traduzido por escrito e nem mesmo mediante a fala. Montaigne não pretende conhecer alguma verdade, por isso fica difícil, nesse ponto, compará-lo com Platão.

O grande absurdo que atravessa a escrita é sua relação estreita com a morte, tema esse que é atestado por Platão na sua denúncia de que a escrita é inumana, antinatural e destrutiva. Em Montaigne, a escrita contribui prioritariamente como exercício de preparação para a morte, escrever é uma experiência de proximidade com a finitude da vida, pela angústia com a qual o escritor se defronta depois de abrir mão do aqui e agora.

\section{Referências}

BURKE, Peter. Montaigne. Tradução de Jaimir Conte. São Paulo: Edições Loyola, 2006.

BURKE, Peter. Montaigne y el arte del diálogo. ABCD las letras y las artes, Madrid, 2008. Disponível em

http://hemeroteca.abc.es/nav/Navigate.exe/hemeroteca/madrid/cultural/200 8/08/30/005. html. Acesso em: 13 abr. 2019.

DERRIDA, Jacques. A farmácia de Platão. Tradução de Rogério Costa. São Paulo: Editora Iluminuras, 2005.

DIÓGENES LAÊRTIOS. Vidas e doutrinas dos filósofos ilustres. Tradução de Mário da Gama Kury. $2^{a}$ edição. Brasília: Editora Universidade de Brasília, 2008. 
DUPONT, Ariette. La structure dialogique des Essais de Montaigne. MCGlll

Unlverslty, Montreal: Thesis for the degree of Master of Art, 1983.

JURADO, Francisco. La oralidad escrita del saber: Aulo Gelio e Michel de

Montaigne. Studia Philologica Valentina, Madrid, v. 12, n. 9, p. 71-83, 2010.

MONTAIGNE, Michel de. Ensaios. Tradução de Sérgio Milliet. Porto Alegre: Editora Globo S.A., 1972.

MONTAIGNE, Michel de. Les Essais. Édition de Pierre Villey. Paris: Presses Universitaires de France, 1992.

NIETZSCHE, Friedrich. Gesammelte Werke: Vierter Band. München: Musarion Verlag, 1953.

ONG, Walter. Oralidade e cultura escrita: a tecnologização da palavra. Tradução Enid Abreu Dobránzxky. Campinas: Papirus Editora, 1998.

PLATÃO. A República. Tradução de Jacó Guinsburg. São Paulo: Editora Perspectiva, 2012.

PLATÃO. Fedro. Tradução e Notas de Pinharanda Gomes. Lisboa: Guimarães Editores, 1989.

PLATÓN. Cartas. Traducciones, Introducciones y notas por Juan Zaragoza y Pilar Gómez Cadó. Madrid: Editorial Gredos, 1992.

REALE, Giovanni. Per una nuova interpretazione di Platone alla luce delle 'Docttrine non scritte'. Milano: Editore Bompiani, 2014.

REALE, Giovanni. Platão. Tradução Henrique de Lima Vaz e Marcelo Perine. São Paulo: Edições Loyola, 2007.

REIS, Marcus. O Fedro e a escrita. Anais de Filosofia Clássica, Vol. 2, N 4, 2008, pp. 70-87. 
RICHARD, Marie-Dominique. L'enseignement oral de Platon. Paris: Les Éditions du Cerf, 2005.

SCHLEIERMACHER, Friedrich. Introdução aos diálogos de Platão. Tradução de Georg Otte. Belo Horizonte: Editora da UFMG, 2002.

STAROBINSKI, Jean. Montaigne em movimento. Traduzido por Maria Lúcia Machado. São Paulo: Companhia das Letras, 1992.

SZLEZÁK, Thomas. Le plaisir de lire Platon. Paris: Éditions du Cerf, 1996.

TOURNON, André. Montaigne. Tradução de Edson Querubini. São Paulo: Discurso Editorial, 2004.

TRABATTONI, Franco. Jacques Derrida e le origini greche del logocentrismo (Platone e Aristoteles). Firenze: Rivista Iride, $\mathrm{N}^{\circ}$ 3, 2004, pp. 547-558.

TRABATTONI, Franco. La verità nascosta: oralità e scrittura in Platone e nella cultura greca classica, Roma: Editore Carocci, 2005.

TRABATTONI, Franco. Platão. Coimbra: Editora Annablume, 2012.

Referência para citação deste artigo ALONSO, Bruno. Oralidade, Escrita e Estilo em Platão e Montaigne. Revista PHILIA|Filosofia, Literatura \& Arte, Porto Alegre, volume 1, número 2, p. 124 -145 , outubro de 2019. 